\title{
多次元尺度構成法による 家庭電気製品の分類
}

\author{
岡太 涁 訓 \\ 立教大学社会学部 \\ 大隅 美子 \\ 慶応義熟大学工学部
}

要 旨 家庭電気製品 22 種について, それぞれの購入先選択理由（10 個）を調查したデータをもとにして，購入先選択理由の似た製品同志は距 離が小さく，購入先選択理由の似ていない製品同志は距離が大きくなるよ らな，製品の多次元的配置を，多次元尺度構成法によって求めた，結果 は，3次元の配置となり，3本の軸は，それぞれ (1) 価格 (2) 品揃え (3) 人間関係，フフターサービス といら解秎が与克られた。 また售品の 多次元的配置に扎いて，たがいに近くに位置している製品をまとめること によって，22 種の製品を 6 個のグループに分類することができた．

製品の多次元的配置は，(1) 製品間の購入先選択理由の違いを示寸指標 をKendall 順位相関係数をもとに作り，(2)この指標を，Kruskal の多 次元尺度構成法で分析することによって得た。

この計算手続の特徵は, 計量心理学での perceptual structure に個人差 がある場合の分析方法と同椂の効果を持っていることである.

1. 目的

家庭電気製品は，たとえばデパート，秋葉原，近所にある小売店のように，さ まざまなところで購入することができる、購入希望者は，多くの販売先から1つ の購入先を決定するが，この場合に，どのよらな理由から購入先を選択している のであらうか，とらぬ゙ん購入する電気製品炕よって異なるはずである．カラーテ レビ，ステレオを購入する場合と，電球，乾電池を購入する場合が同じはずはな 
い．前者のような製品を瞵入する場合には，カタログを集めいろいろ検討してから購入先を决めることが多く， 後者のよらな製品の場合には，通りがかりにある店で十分間に合ら場合が多い。

このように, 電気製品を購入する場合に，製品によって購入先選択理由が巽なりそれに伴って購入先も変わっ てくる.

そこで，主要家庭電気製品 22 品目について購入先選択理由, 睠入先を調査し,

(1) 多次元尺度構成法によって戝入先選択理由の似た製品同䓌は距離が小さく，購入先選択理由の似ていない 製品同志は距離が大きくなるような，電気製品の多次元的配置を求め，

これをもとに，

(2) 購入先選択理由の中から主要な理由を選び出し,

(3) 電気製品の多次元的配䁂で，おたがいに近くにある電気製品をまとめていくつかのグループを作ることに より，電文製品を購入先選択理由から分類し，それぞれのグループと購入先の関係を教党る

ことにした.

\section{2. デー タ}

分析には，日本電機工業会の調查結果の一部をデータとして用いた，日本電機工業会の調査 ${ }^{[1]}$ では，主都圈か ら抽出した 616 世帯について, 生活水準, 世帯主年齢，世带主職業，土着性，住居形態，電気製品別所有非所 有, および昭和 43 年 1 月から昭和 45 年 8 月までの間に調査対象世帯の購入した電気製品とその購入先，購入先 選択理由を調査している.ここでは購入先選択理由によって電気䑾品の多次元尺度構成を行ない，結果の解釈に 購入先を考慮した.

調查対象となった電気製品は。

1) カラーテレビ

2) ルームクーラー

3) ステレオ

4) 電子レンジ

5）電気冷蔵庫（ガスを除く）

6) 電気掃除機

7) 電気洗濯機

8）白黒テレビ

9）テープレコーダー（カセット式を含む）

10）扇風機

11) ジューサー，ミキサー

12）電気毛布

13）電気釜（ガスを除く）

14) トースタ一

15）アイロン

16）電気スタンド 

17) ラジオ（トランジスタラジオのみ）
18) ヘヤードライヤー
19）䉓気加多そり
20）䨖気こたつ
21）換気扇
22）電球，䖝光灯ランプ，ソケット，乾電池

の 22 種類である.これらの電気製品について購入先選択理由として。
1) 安 い
2）購入条件がよい
3）アフターサービスがよい
4) 品揃えが豊富
5）ブランドまたは店が信用できる
6）縁故，会社関係
7）通りがかり
8）セールスマンから
9）交通の便がよい
10）いきつけで安心
11) その他

を、また購入先として
1）小売店
2) 量勋店
3）スーパーマーケット
4) デパート
5) 秋葉原
6) 艺の他

をとりあげて調査しまとめた結果を表 1 ，表 2 に示す。

\section{3. 多次元尺度構成法}

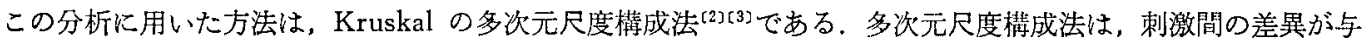
えられた時にここれもとにして刺激の多次元的配置を求める方法である. Kruskal の方法に括いては，与克ら れた刺激間の盖異の大きさの順序と，刺激の配置に括ける刺激間の距離の大ささの順序が可能なかぎり一致する

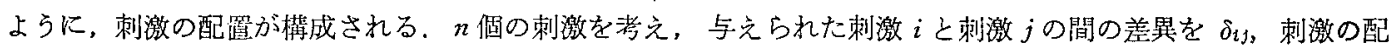
置に叔りる刺激 $i$ と刺激 $j$ の間の距離を $d_{i j}$ とする，与えられた刺激間の差異の大きさの順序が，

$$
\delta_{i_{1} j_{1}}<\delta_{t_{2} j_{2}}<\cdots \cdots<\delta_{t_{M} j_{M}} \quad\left(M={ }_{n} \mathrm{C}_{2}\right)
$$

である時に, 可能なかぎり 
表: 1. 繁品別購入珗選択理由

\begin{tabular}{|c|c|c|c|c|c|c|c|c|c|c|c|c|c|}
\hline 製 & 購入総数 & $\begin{array}{c}\text { 択理由 } \\
\%\end{array}$ & 1. 安W & $\begin{array}{l}2 . \text { 購入 } \\
\text { 条件がよ } \\
\text { W }\end{array}$ & $\begin{array}{l}3 . ア 7 \\
\text { ターサーサ } \\
\text { ビスのよ } \\
\text { さを考光 } \\
\text { て }\end{array}$ & $\begin{array}{l}4 \cdot \text { 品揃 } \\
\text { えが豊蜜 }\end{array}$ & $\begin{array}{l}5 . . \text { ブラ } \\
\because \text { ド又は } \\
\text { 店を信用 }\end{array}$ & $\begin{array}{l}6 \text {. 縁故 } \\
\text { 会社関係 }\end{array}$ & $\begin{array}{l}\text { 7.通り } \\
\text { ががり }\end{array}$ & $\begin{array}{l}\text { 8.セー } \\
\text { ルスマン } \\
\text { から }\end{array}$ & $\begin{array}{l}9 . \text { 交通 } \\
\text { の便が } \\
\text { 心 }\end{array}$ & $\begin{array}{l}10 . い き \\
\text { 心けで安 }\end{array}$ & 11. その \\
\hline 1 & カラーテレビ & 273 & 26.7 & 1.8 & 10.3 & 4.8 & 4.4 & 15.0 & 0.4 & 0.4 & 5.5 & 27.8 & 2.9 \\
\hline 2 & ルームクーラー & 74 & 17.5 & 1.4 & 2.7 & 4.1 & 4.1 & 16.2 & 0.0 & 0.0 & 5.4 & 32.3 & 16.2 \\
\hline 3 & ス $テ$ レ & 98 & 22.4 & 10.2 & 0.0 & 11.2 & 6.1 & 14.3 & 5.1 & 0.0 & 5.1 & 13.3 & 12.2 \\
\hline 4 & 電 子 レ ン ジ & 18 & 22.2 & 0.0 & 0.0 & 0.0 & 11.1 & 16.7 & 5.6 & 0.0 & 0.0 & 33.3 & 11.1 \\
\hline 5 & 電 気 冷 蔵 庫 & 165 & 28.5 & 3.0 & 3.6 & 6.1 & 8.5 & 17.0 & 0.6 & 0.6 & 6.7 & 18.8 & 6.7 \\
\hline 6 & 電 気 掃 除 機 & 217 & 26.7 & 2.8 & 2.3 & 3.7 & 3.2 & 13.8 & 2.8 & 0.5 & 10. 1 & 24.9 & 9.3 \\
\hline 7 & 電 気 洗 濯 機 & 268 & 29.5 & 2.9 & 4.3 & 4.3 & 12.3 & 12.3 & 1.1 & 0.7 & 7.6 & 24.9 & 0.0 \\
\hline 8 & 白 黒 $テ$ レ ビ & 143 & 30.8 & 0.0 & 6.3 & 2.1 & 3.5 & 12.6 & 2.1 & 0.0 & 9.8 & 28.0 & 4.9 \\
\hline 9 & テープレコーダー & 97 & 21.6 & 1.0 & 4.1 & 5.2 & 5.2 & 12.7 & 3.1 & 1.0 & 5.2 & 24.7 & 16.5 \\
\hline 10 & 風 & 190 & 28.7 & 2.6 & 0.5 & 3.7 & 6.3 & 9.5 & 1.6 & 0.0 & 11.6 & 23.7 & 11.6 \\
\hline 11 & 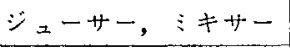 & 102 & 30.4 & 1.0 & 2.0 & 2.0 & 2.9 & 10.8 & 7.8 & 0.0 & 10.8 & 20.6 & 10.9 \\
\hline 12 & 電 気 毛 布 & 78 & 24.4 & 1.3 & 0.0 & 3.8 & 1.3 & 11.5 & 1.3 & 0.0 & 11.5 & 25.6 & 19.3 \\
\hline 13 & 電 & 77 & 27.3 & 0.0 & 0.0 & 2.6 & 9.1 & 10.4 & 1.3 & 0.0 & 15.6 & 31.2 & 2.6 \\
\hline 14 & $卜 \quad-x$ \& & 113 & 27.3 & 0.0 & 0.7 & 2.1 & 4.9 & 7.7 & 5.6 & 0.0 & 13.3 & 27.3 & 11.1 \\
\hline 15 & ア $1 \quad \square$ & 107 & 24.3 & 0.0 & 1.9 & 6.5 & 3.7 & 8.4 & 8.4 & 0.0 & 14.0 & 22.4 & 10.3 \\
\hline 16 & 電 気 スタンド & 156 & 18.6 & 0.6 & 1.3 & 7.1 & 2.6 & 6.4 & 10.3 & 0.0 & 12.2 & 22.4 & 18.6 \\
\hline 17 & ラ $\quad \ddot{*}$ & 120 & 30.0 & 0.8 & 2.5 & 4.2 & 5.8 & 6.7 & 5.0 & 0.0 & $13: 3$ & 20.8 & 10.8 \\
\hline 18 & ヘヤードライヤー & 105 & 35.2 & 0.0 & 2.9 & 3.3 & 0.0 & 10.5 & 7.6 & 1.0 & 11.4 & 20.0 & 7.6 \\
\hline 19 & 電 気かみとり & 124 & 22.6 & 0.8 & 1.6 & 8.1 & 0.8 & 6.5 & 15.3 & 0.8 & 16.1 & 19.4 & 8.1 \\
\hline 20 & 電 気 こたつ & 139 & 23.7 & 0.0 & 5.8 & 3.6 & 2.2 & 8.6 & 4.3 & 0.0 & 9.4 & 29.5 & 12.9 \\
\hline 21 & 気 & 101 & 25.7 & 2.0 & 4.0 & 1.0 & 2.0 & 8.9 & 0.0 & 1.0 & 18.8 & 23.8 & 12.8 \\
\hline 22 & $\begin{array}{l}\text { 電 球, 螢 光電灯 } \\
\text { 池 }\end{array}$ & 394 & 8.9 & 0.0 & 1.3 & 1.5 & 1.0 & 3.6 & 11.4 & 0.0 & 36.8 & 22.6 & 12.9 \\
\hline
\end{tabular}


表 2. 繁品別睡入先

\begin{tabular}{|c|c|c|c|c|c|c|c|}
\hline 製 & 品 & .1. 小苧店 & 2. 量販店 & 3. $\begin{array}{r}\text { スーハ } \\
\text {-マ- } \\
\text { ケット }\end{array}$ & 4. デパート & 5. 秋葉原 & 6. その他 \\
\hline 1 & カラーテレビ & 51.6 & 3.7 & 4.5 & 5.1 & 11.7 & 26.4 \\
\hline 2 & ルームク-ラ- & 47.3 & 0.0 & 0.0 & 12.2 & 16.2 & 24.4 \\
\hline 3 & $\pi \quad F \quad v \quad t$ & 25.5 & 4.1 & 3.1 & 22.4 & 26.5 & 17.4 \\
\hline 4 & 電 子レンジ & 44.4 & 0.0 & 5.6 & 5.6 & 11.1 & 33.3 \\
\hline 5 & 電 気 冷 蔵 車 & 42.4 & 4.8 & 1.8 & 10.2 & 17.6 & 23.0 \\
\hline 6 & 電 気 掃 除 機 & 45.1 & 6.0 & 3.2 & 10.6 & 18.4 & 16.2 \\
\hline 7 & 電 気 洗 濯 機 & 47.1 & 5.2 & 3.7 & 9.4 & 15.7 & 18.5 \\
\hline 8 & 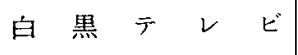 & 47.6 & 8.4 & 2.8 & 6.3 & 18.2 & 16.2 \\
\hline 9 & テープレコーダ- & 25.8 & 2.1 & 0.0 & 14.5 & 34.0 & 23.8 \\
\hline 10 & 風 & 40.0 & 5.3 & 4.2 & 14.2 & 20.0 & 15.9 \\
\hline 11 & ジューサー, ミキキー & 42.1 & 5.9 & 2.9 & 9.8 & 21.6 & 17. 6 \\
\hline 12 & 電 気 毛 布 & 37.2 & 6.4 & 6.4 & 9.0 & 14.1 & 25.7 \\
\hline 13 & 電 気 釜 & 53.3 & 7.8 & 5.2 & 10.4 & 11.7 & 11.7 \\
\hline 14 & $1-x \&-$ & 44.1 & 5.6 & 8.4 & 7.7 & 17.5 & 16.8 \\
\hline 15 & $7 \quad 1 \quad 2 \quad 2$ & 43.0 & 7.5 & 7.5 & 6.5 & 17.8 & 16.1 \\
\hline 16 & 電気スタンド & 43.6 & 5.8 & 5.8 & 16.7 & 17.9 & 9.7 \\
\hline 17 & $\ddot{z}$ & 30.0 & 0.8 & 4.2 & 11.7 & 32.5 & 20.1 \\
\hline 18 & へヤードライヤー & 38.1 & 1.9 & 12.4 & 11.5 & 17.1 & 18.2 \\
\hline 19 & 電気かみそり & 33.9 & 2.4 & 6.5 & 14.5 & 20.2 & 21.2 \\
\hline 20 & 電 気こたつ & 47.5 & 7.2 & 7.2 & 7.9 & 15.8 & 14.4 \\
\hline 21 & 换 気 扇 & 54.2 & 3.0 & 3.0 & 1.0 & 22.8 & 15.9 \\
\hline 22 & 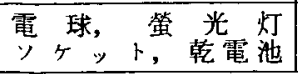 & 74.2 & 3.6 & 9.9 & 1.3 & 5.5 & 9.0 \\
\hline
\end{tabular}




$$
d_{i_{1} j_{1}} \leqq d_{i_{2} j_{2}} \leqq \cdots \cdots . . d_{i_{M} j_{M}}
$$

であるような $d_{\imath}$ をもたらす刺激の配置を求めることが目標である.つまり $\delta_{i j}$ と $d_{i j}$ の関係は, 図 1 に示す

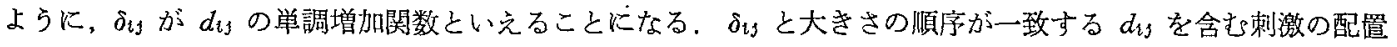
は, 刺激の配置の次元数を增加させれば常に可能であるが, 次元数の大きい刺激の配置は, その状態を具体的に 把握することが困難である. そこで， $\delta_{i j}$ と $d_{i j}$ の単調増加な関係を多少犠牲にして，可能なかぎり次元数の少 ない刺激の配置を作ることになる．ここで， $\delta_{t j}$ と. $d_{i j}$ の単調增加な関係がぞの程度くずされているかる示す指 標がストレスであり， $\delta_{i j}$ と大きさの順序が一致する $d_{i s}$ を含む刺激の配蹎のストレスは0である. Kruskal の 方法を実際に用いる場合には，あらかじめ刺激の配置の次元数を何程類か想定し，それぞれの次元数に打いてス トレスが最小になる刺激の配㯰を見付け出し，次の二つの基準

(1) 次元数ごとに，刺激の個数の各々に対して与えられているストレスの基準の值 ${ }^{[4]}$.

(2) 刺激の配置の解釈が容易であること.

から刺激の配置を決定する。

Kruskal の方法では $\delta_{t}$ の大きさの順位だけが計算手続で用いられているにすぎない，そこで，このよらな方 法をノンメトリックな多次元尺度構成法と呼ぶ.

この分析は, 購入先選択理由の違いを表示す電気製品の多次元的配置を求めるのであるから, 購入先選択理由 の違いを反映する笔気製品間の差異を求める必要がある.

電気製品 $i$ と電気製品 $j$ の間の購入先選択理由の違いを表わす $\delta_{i j}$ は，次のようにして求めた.

1）電気製品 $i$ の購入先選択理由 $k$ に対する比率を $p_{i k}$ とし， $p_{i k}$ を逆正弦变換した值を $s_{i k}$ とする.

$$
s_{i k}=\sin ^{-1} p_{i l i}
$$

2）戝入先選択理由の中から「その他」を除いた䀧入先選択理由の組合せ 45 個を作り，この組み合せごとに $s_{i k}$ の差

$$
\left(s_{i 1}-s_{i 2}\right),\left(s_{i 1}-s_{l 3}\right), \cdots,\left(s_{t 2}-s_{l 3}\right), \cdots, \quad\left(s_{i 9}-s_{i 10}\right)
$$

茟水ひるこここて

$$
t_{t k l}=s_{\imath k}-s_{\imath l}\left(\begin{array}{l}
i=1, \cdots, 22 ; k=1, \cdots, 9 ; \\
l=2, \cdots, 10 ; k<l
\end{array}\right)
$$

とする.

3） $t_{t k l}$ の緦対值と $t_{j k l}$ の緦対值，すなわち,

$$
\begin{aligned}
& \left\{\left|t_{t 12}\right|,\left|t_{i 13}\right|, \cdots,\left|t_{i 23}\right|, \cdots,\left|t_{t_{10} 10}\right|\right\} \quad \text { 之 } \\
& \left\{\left|t_{j 13}\right|,\left|t_{j 13}\right|, \cdots,\left|t_{j 23}\right|, \cdots,\left|t_{j 910}\right|\right\}
\end{aligned}
$$

の Kendall 順位相関保数を $r_{i j}$ とし，

$$
\delta_{i j}=1-r_{i j}
$$

と定義した。

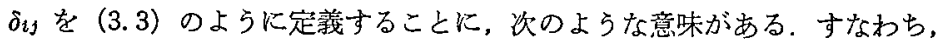

$$
\left(s_{i 1}, s_{i 2}, \cdots, s_{i 10}\right) \quad(i=1, \cdots, 22)
$$

は 1 次元上にプロットすることができる，そして，これは電気製品 $i$ の購入先選択理由の特徵を表わす購入先選

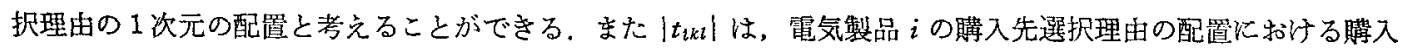




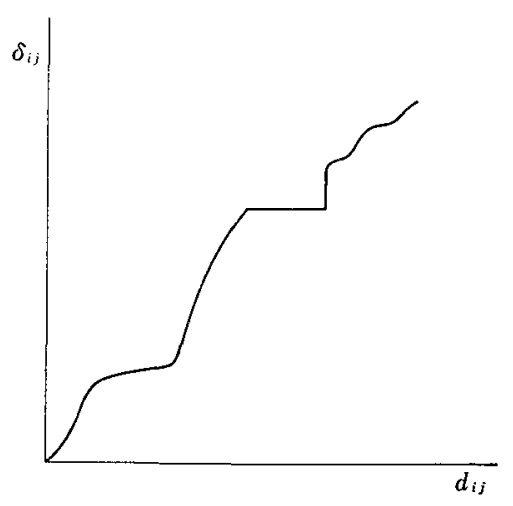

図 1. $\delta_{i j}\left\llcorner d_{i j}\right.$ の関係

先選択理由 $k$ と購入先選択理由 $l$ の間の距離と考えることができ

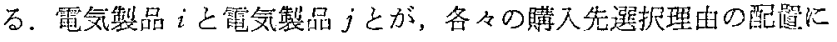
扣いて，購入先選択理由閐の距離の大ささの順序が同一である場合 には， $r_{i j}=1$ となり $\delta_{i j}=0$ となる。また瞒入先選択理由間の距離 の大きさの順序が正反対の昜合には， $r_{i j}=-1$ となり $\delta_{i j}=2$ とな

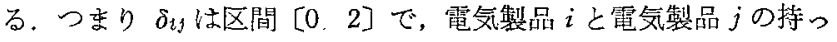
ている購入先選抧理由の配置の似ている程度を反映しているのであ る.このことは，この分析で用いられた計算手続が，計量心理学で の perceptual structure（矌入先選択理由の配置に対応）に個人差 (電氮製品間の美に対応) がある場合の尔析手法である Tucker と Messick の多次元尺度構成法 ${ }^{[5]}$ と同様な効果を持っていることを示 している[6][7][8].

前述のようにして得られた $\delta_{i j}$ Kruskal のち法で分析すれば，購入先選択理由の違いを表わす電気製品の 多次元的配置が得られる。

\section{4. 結果}

表 1 のデータから電気製品間の差異 $\delta_{i j}$ を求めた。これを表 3 に示す。

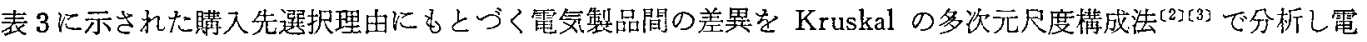
気製品の配置を，1次元〜3次元について求めた，求められた配置の最小ストレスは，

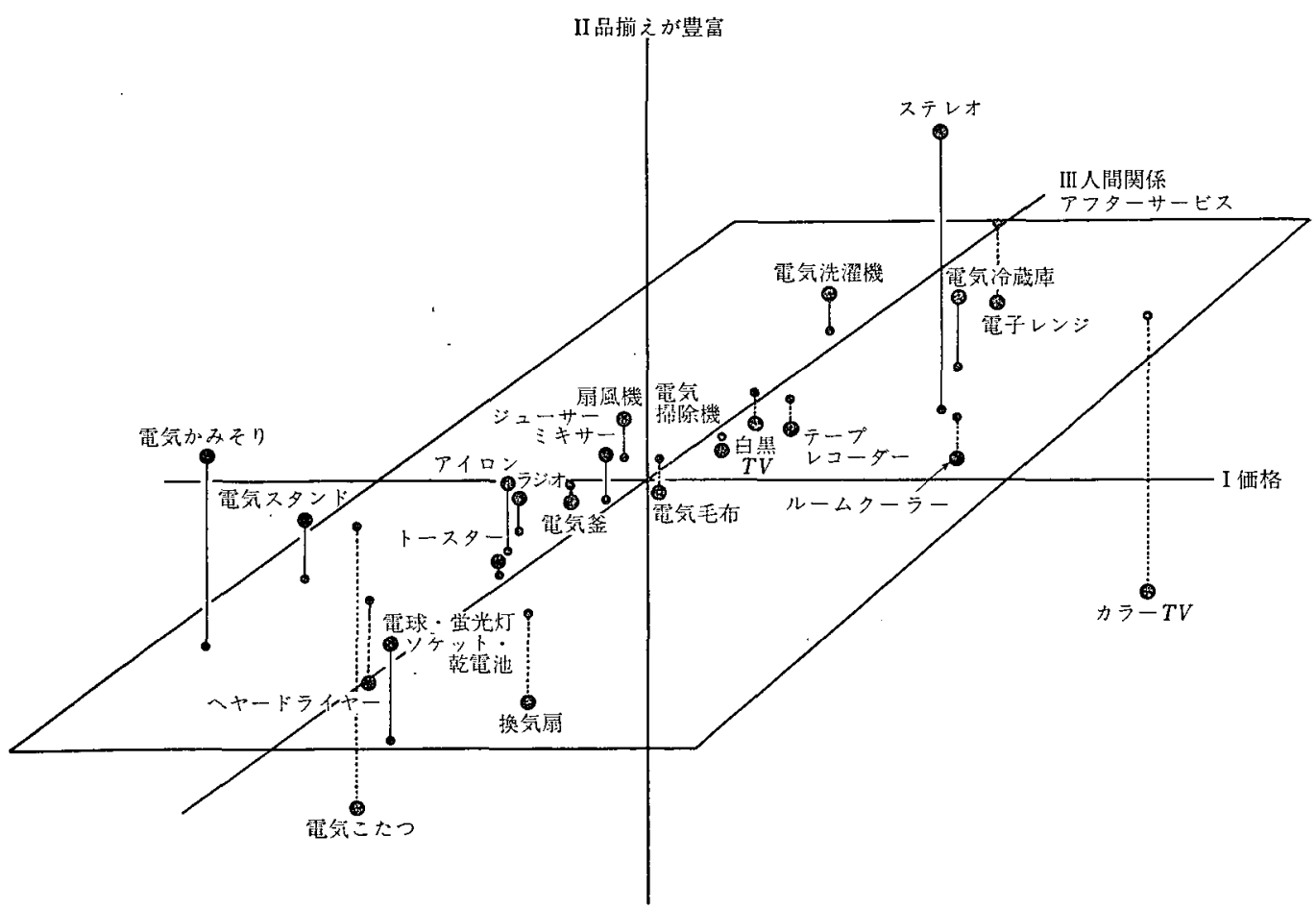

図 2、製品の配置図 
偯

3. 製品間の 差異

\begin{tabular}{|c|c|c|c|c|c|c|c|c|c|c|c|c|c|c|c|c|c|c|c|c|c|c|}
\hline & & $\begin{array}{c}1 \\
\text { カラ } \\
\frac{\bar{T}}{\nu ヒ ゙}\end{array}$ & $\begin{array}{l}2 \\
ル- \\
ム \eta \\
-5 \\
-\end{array}$ & $\begin{array}{c}3 \\
ス \bar{v} \\
レ オ\end{array}$ & $\begin{array}{c}4 \\
\text { 電子 } \\
レ \\
シ ゙\end{array}$ & $\begin{array}{c}5 \\
\text { 電気 } \\
\text { 泠蔵 } \\
\text { 庫 }\end{array}$ & $\begin{array}{c}6 \\
\text { 電気 } \\
\text { 掃除 } \\
\text { 機 }\end{array}$ & $\begin{array}{c}7 \\
\text { 電気 } \\
\text { 洗濯 } \\
\text { 機 }\end{array}$ & $\begin{array}{c}8 \\
\text { 白黑 } \\
\bar{\tau} レ \\
\text { ビ }\end{array}$ & $\begin{array}{c}9 \\
\text { テ̄- } \\
\text { プレ } \\
\beth \text { - } \\
\text { ダ- }\end{array}$ & $\begin{array}{c}10 \\
\text { 扇風 } \\
\text { 機 }\end{array}$ & 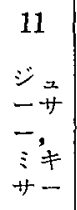 & $\left\{\begin{array}{c}12 \\
\text { 電気 } \\
\text { 毛布 }\end{array}\right.$ & $\begin{array}{c}13 \\
\text { 霓気 } \\
\text { 金 }\end{array}$ & $\begin{array}{l}14 \\
\text { ト́ } \\
\text { ス夕 } \\
-\end{array}$ & $\begin{array}{l}15 \\
\text { アイ } \\
x^{2}\end{array}$ & 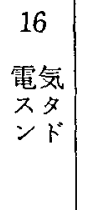 & $\begin{array}{l}17 \\
\text { ラジ } \\
才\end{array}$ & $\begin{array}{c}18 \\
\\
-7 \\
-1 \\
\bar{j} 1 \\
+-\end{array}$ & $\begin{array}{c}19 \\
\text { 電気 } \\
\text { か子 } \\
\text { そb }\end{array}$ & $\begin{array}{c}20 \\
\text { 電気 } \\
こ た ~ \\
こ\end{array}$ & $\begin{array}{c}21 \\
\text { 換気 }\end{array}$ \\
\hline 2 & ル- & 0.503 & & & & & & & & & & & & & & & & & & & & \\
\hline 3 & $\begin{array}{llll} & \boldsymbol{\tau} & & \end{array}$ & 0.674 & 0.575 & & & & & & & & & & & & & & & & & & & \\
\hline 4 & 電 子 $レ$ ン $シ ゙$ & 0.543 & 0.431 & 0.700 & & & & & & & & & & & & & & & & & & \\
\hline 5 & 電 気 冷 蔵 庫 & 0.523 & 0.361 & 0.462 & 0.470 & & & & & & & & & & & & & & & & & \\
\hline 6 & 電 㚇 掃 除 機 & 0.513 & 0.381 & 0.508 & 0.512 & 0.348 & & & & & & & & & & & & & & & & \\
\hline 7 & 電 気 洗 濯 機 & 0.509 & 0.493 & 0.582 & 0.350 & 0.369 & 0.384 & & & & & & & & & & & & & & & \\
\hline 8 & 白 黒 テ レ ビ & 0.455 & 0.424 & 0.542 & 0.432 & 0.370 & 0.230 & 0.267 & & & & & & & & & & & & & & \\
\hline 9 & テーブレコーダー & 0.443 & 0.287 & 0.517 & 0.427 & 0.342 & 0.254 & 0.346 & 0.263 & & & & & & & & & & & & & \\
\hline 10 & 風 & 0.570 & 0.426 & 0.515 & 0.559 & 0.432 & 0.260 & 0.353 & 0.317 & 0.326 & & & & & & & & & & & & \\
\hline 11 & $\dot{*}=ー+一, \quad \Sigma \neq サ ー$ & 0.618 & 0.444 & 0.510 & 0.569 & 0.420 & 0.357 & 0.401 & 0.322 & 0.369 & 0.273 & & & & & & & & & & & \\
\hline 12 & 電 気 毛 & 0.534 & 0.405 & 0.523 & 0.516 & 0.341 & 0.230 & 0.440 & 0.313 & 0.330 & 0.305 & 0.334 & & & & & & & & & & \\
\hline 13 & 電 気 & 0.624 & 0.388 & 0.600 & 0.540 & 0.438 & $(1.299$ & 0.412 & 0.362 & 0.328 & 0.167 & 0.311 & 0.267 & & & & & & & & & \\
\hline 14 & $1-\pi g$ & 0.631 & 0.530 & 0.570 & 0.595 & 0.549 & 0.395 & 0.466 & 0.392 & 0.411 & 0.323 & 0.322 & 0.358 & 0.311 & & & & & & & & \\
\hline 15 & $7 \quad 1 \quad \square$ & 0.673 & 0.433 & 0.532 & 0.630 & 0.500 & 0.352 & 0.520 & 0.387 & 0.392 & 0.359 & 0.299 & 0.313 & 0.308 & 0.263 & & & & & & & \\
\hline 16 & 電気スタンド & 0.751 & 0.551 & 0.681 & 0.668 & 0.589 & 0.463 & 0.602 & 0.531 & 0.470 & 0.425 & 0.430 & 0.402 & 0.358 & 0.356 & 0.274 & & & & & & \\
\hline 17 & ラ $\quad \ddot{\prime}$ & 0.693 & 0.482 & 0.565 & 0.608 & 0.459 & 0.343 & 0.464 & 0.363 & 0.407 & 0.313 & 0.236 & 0.361 & 0.266 & 0.276 & 0.243 & 0.384 & & & & & \\
\hline 18 & へヤートラライー & 0.750 & 0.567 & 0.674 & 0.685 & 0.506 & 0.453 & 0.583 & 0.496 & 0.548 & 0.439 & 0.335 & 0.409 & 0.422 & 0.329 & 0.367 & 0.371 & 0.343 & & & & \\
\hline 19 & 電気か子名り & 0.762 & 0.698 & 0.670 & 0.809 & 0.679 & 0.580 & 0.656 & 0.626 & 0.599 & 0.529 & 0.491 & 0.548 & 0.545 & 0.425 & 0.423 & 0.341 & 0.482 & 0.473 & & & \\
\hline 20 & 電 気 こた & 0.742 & 0.626 & 0.834 & 0.671 & 0.663 & 0.539 & 0.660 & 0.516 & 0.563 & 0.589 & 0.497 & 0.486 & 0.492 & 0.510 & 0.534 & 0.572 & 0.483 & 0.457 & 0.692 & & \\
\hline 21 & 換 気 扇 & 0.599 & 0.561 & 0.632 & 0.715 & 0.557 & 0.475 & 0.548 & 0.442 & 0.537 & 0.382 & 0.405 & 0.451 & 0.425 & 0.293 & 0.425 & 0.473 & 0.372 & 0.365 & 0.443 & 0.585 & \\
\hline 22 & 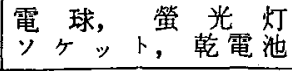 & 0.861 & 0.604 & 0.756 & 0.788 & 0.745 & 0.683 & 0.748 & 0.677 & 0.648 & 0.624 & 0.528 & 0.623 & 0.571 & 0.454 & 0.459 & 0.505 & 0.508 & 0.531 & 0.541 & 0.676 & 0.507 \\
\hline
\end{tabular}


表 4. 留 品 の 配 置

\begin{tabular}{|c|c|c|c|c|}
\hline \multicolumn{2}{|c|}{ 製 } & I & II & III \\
\hline 1 & カ $ラ-テ レ ヒ ゙$ & 0.9256 & -1.0035 & 1. 0547 \\
\hline 2 & ル-ムク- & 0.7790 & -0.1362 & 0.3768 \\
\hline 3 & $\begin{array}{llll} & \bar{T} & \llcorner & オ\end{array}$ & 0.7212 & 1.3393 & 0.4087 \\
\hline 4 & 電 子レンジ & -0.0049 & -0.2767 & 1.5384 \\
\hline 5 & 電 気 冷 蔵 庫 & 0.5399 & 0.2788 & 0.6617 \\
\hline 6 & 電 気 掃 除 機 & 0.0145 & $-0.0145^{\circ}$ & 0.3226 \\
\hline 7 & 電 気 洗 濯 機 & -0.1039 & 0.1293 & 0.9302 \\
\hline 8 & 白 黑 テ レ ビ & -0.0152 & -0.1177 & 0.5035 \\
\hline 9 & テープレコーダー & 0.2391 & -0.0822 & 0.4593 \\
\hline 10 & 扇風 & -0.2049 & 0.1623 & 0.1522 \\
\hline 11 & 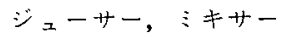 & -0.0131 & 0.1852 & -0.1545 \\
\hline 12 & 電 気 毛 布 & -0.0616 & -0.1447 & 0.1336 \\
\hline 13 & 電＜wide>気 & -0.2541 & -0.0376 & -0.0199 \\
\hline 14 & ト 一 - ス 夕 & -0.1043 & 0.0154 & -0.5246 \\
\hline 15 & $\begin{array}{llll}7 & 1 & \square & \end{array}$ & -0.1936 & 0.2432 & -0.4061 \\
\hline 16 & 電 気 スタンド & -0.7074 & 0.2315 & -0.6225 \\
\hline 17 & $\ddot{z}$ & -0.2367 & 0.0942 & -0.2882 \\
\hline 18 & へヤードライヤー & -0.4039 & -0.3120 & -0.7480 \\
\hline 19 & 電気かみそり & -0.7579 & 0.7054 & -1.0868 \\
\hline 20 & 電 気こたつ & -0.7723 & -1.2683 & -0.2791 \\
\hline 21 & 換 気 扇 & 0.2185 & -0.3608 & -0.7858 \\
\hline 22 & 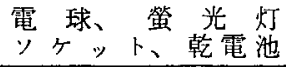 & 0.3958 & 0.3696 & -1.6263 \\
\hline
\end{tabular}




$$
\begin{array}{ll}
1 \text { 次元 } & 0.252 \\
2 \text { 次元 } & 0.119 \\
3 \text { 次元 } & 0.085
\end{array}
$$

であった，最小ストレスの值だけから考えれば，2次元の配琶を採用することもできるが(4)，ここでは，電気製 品の配置の解积を考虑して，3次元に新ける配置を採用した、これを表 4 に示し，配置㘠を図 2 亿示す。

\section{5. 検討}

図 2 の配置の各朝の意味を，表1から考えてみると

I 軸 価格

叶軸 品揃支

III軸 人間関係,アフターサービス

という解积が可能である．これより電気製品を購入する際に購入先を選抧する主要な理由として，次のような 3 要因が考えられていると思われる.

1) 価格要因

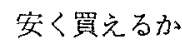

2) 品揄光要因

品揃えが賈富で各種の品物を比較検討できるか

3) 信頼要因

アフターサービスや人間関係が信頓できるか.

さらに図 2 から，購入先選択理由から考えた電気製品のグループ
A グループ
カラーテレビ
ルームクーラー
電子レンジ
B グループ
電気冷蔵庫
電気洗濯機
電気掃除機
Cグループ
白黒テレビ
テープレコーダー
$\mathrm{D}$ グループ
ステレオ
Eグループ
電気かみそり
電気スタンド 


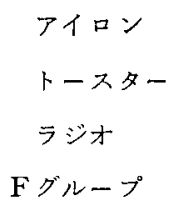

の6グループが考えられる.

これら6グループの特徵を考え，購入先はどこが多いかを変 2 から調べると，次のよらなことが挙げられる。

\section{A グループ}

信頼要因が重視されている，さらに，価格要因も考えられている，矌入先は小壳店が多く，秋葉原，デパ一 トがこれに次いでいる。

\section{Bグループ}

信頼, 品揃え, 価格の 3 要因が同じように重視されている. 睡入先は小売店, 秋葉原, デパートの覑であ 子。

\section{Cグループ}

価格，信頼の 2 要因が重視されている，購入先は，白黒テレビにおいては小売店，秋葉原，量販店の順であ り,テープレコーダーに拈いては秋葉原, 小売店, デパートの順になっている.テープレコーダーの場合の秋 葉原は他の製品と比較して多い.

\section{Dグループ}

品揃息因が特に重視されている。また価格, 信頼の 2 要因も重視されている. 購入先は, 秋葉原, 小売 店，デパートの順となっている，秋葉原と小売店の差は小さく，デパートは他の製品に比較して多い。

\section{Eグループ}

品揃え要因が重視されている，とくに電気かみそりはその傾向が大きい，購入先は，電気スタンド，電気か みそりは小売店，秋葉原，ディ゚ートの順で，トースター，アイロンは小壳店，秋葉原，スーパーマーケットの 順になっている. ラジオは，小売店と秋葉原の位直が逆転し，秋葉原，小売店，デパートの順になっている。

\section{Fグループ}

3 要因とも重視されていない，購入先は，小物は小売占がとび拔けて多く，スーパーマーケット，秋葉原が 続いている，その他の製品では，小売店，秋葉原といら順で，第 3 位は，換気扇，へヤードライヤーはスーパ ーマーケット，その他の製品では，デパートである。 
結果を手法の応用面から芳えた場合には，それぞれの電気製品ごとの購入先選択理由の配置が 1 次元に限定さ れており，手法を十分に生かした分析とはいえない，しかし図2から得られた電気製品のグルーピングは，十分 筋の通ったものと考兄らる(1).今後それぞれの電気製品について，購入先選択理由の配置を多次元にして分析 することが望まれる。

ここで (3. 3) とおいて，2つの電気製品の購入先選択理由の相関をそれぞれの電気製品の購入先選択理由の 比率 $p_{i k}$ を逆正弦変換した值 $s_{i k}(k=1, \cdots, 10)$ 閒の差 $t_{i k l}$ の緦対值 $\left|t_{i k l}\right|$ の Kendall 順位相関保数で考える ことの意味を検討しておく. 今回の場合には， $s_{i k}(k=1, \cdots, 10)$ 間の差の絶対值 $\left|t_{i k l}\right|$ の大きさの順位の情報 を用いていることになる. 他方, 2 つの電気製品の購入先選択理由の相関を $s_{i k}$ の Kendall 順位相関係数で考 えた場合には，sik の大きさの順位といら情報だけを用いていることになる．

一方比率 $p_{i k}$ を逆正弦変換した值 $s_{l j}$ といら数值で与えられた情報から，ての一部すなわら $s_{i k}(k=1, \cdots, 10)$ 間の差の絶対值 $\left|t_{2 k l}\right|$ の大きさの順位のみを用いることは，一見不合理に考えられる.むしろ逆正弦変換した值 $s_{t k}$ そのものを用いたモーメント相関保数を用いた方が情報を十分に生かすという意味があるように思われる。

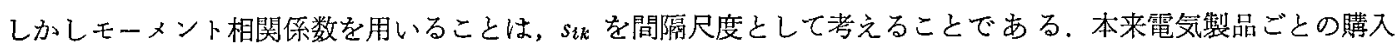
先選択理由の比率 $p_{i k}$ を逆正弦変換した值 $s_{i k}$ は，たとえば温度のように間隔尺度とは考えにくいものである， これに対して Kendall 順位相関保数を $s_{i k}$ に対して適用した場合には， $s_{i k}$ を順序尺度として扱らことになる。 また今回のように， $s_{i k}(i=1, \cdots, 10)$ 間の差の絶対值 $\left|t_{i k l}\right|$ に対して適用した場合には， $s_{i k}$ を高位順序尺度と して扱うことになる．すでに述べたように，電気製品ごとの購入先選択理由の此率 $p_{\imath k}$ を逆正弦変換した值 $s_{\imath k}$ は，間隔尺度とは考学にくい，他方，順序尺度として报ったのでは，あまりにも情報の僅かの部分しか用いてい ない：この点から兩者の中間である高位順序尺度と考えることが適当であると考えたのである。

\section{6. 謝 辞}

この研究は，慶応義塾大学情報科学研究所の 1970 年度特定研究の一部として行なわれたものであり，電子計

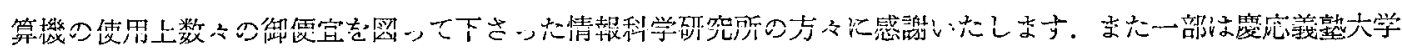
工学部管理工学科のご援助のあったことを記し，同学科の関係者の方々に感謝いたします。またご指導いただい た浦昭二，印東太郎の両教授に厚く感謝いたします。なおデータは株式会社電通の松坂耪宜氏よりご提供いただ いたものであり，結果の解釈について松双氏ょり貴重なご助言をいただいたことを記し，松坂氏をはじめとする 株式会社電通マーケティング局の方々にそのご協力を感謝いたします。るたくにこの論文に有益なご助言を与 えて下さったレフェリー方に厚く感謝いたします。

\section{参考文献}

〔1] 日本電機工業会 (1971)：『昭和 45 年度事業報告』,「将来の家庭電機の流通像 消費者の購買行動の 分析」.

[2] Kruskal, J. B. (1964): Multidimensional Scaling by Optimizing Goodness of Fit to a Nonmetric Hypothesis, Psychometrika, Vol. 29, pp. 1-27.

[3] Kruskal, J. B. (1964) : Nonmetric Multidimensional Scaling; A Numerical Method, Psychometrika, Vol. 29, pp. 115-129.

[4] Klahr, D. (1969): A Monte Carlo Investigation of the Significance of Kruskal's Nonmetric Scaling Procedure, Psychometrika, Vol. 34, pp. 319-330. 
[5] Tucker, L. R. and Messick, S. (1963) : An Individual Differences Model for Multidimensional Scaling, Psychometrika, Vol. 28, pp. 333-367.

[6] Okada, A. and Takeuchi Yoshiko (1971): Nonmetric Multidimensional Scaling of Differences among Type, Psychonomic Science, Vol. 25, pp. 197-198.

〔7]浦昭二, 岡太须訓, 竹内美子（1971）：「尺度構成の一方法とその応用例」, 第 3 回行動計量学シンポ ジゥム発表詥文予稿集, pp. 100-103.

[8] 竹内美子 (1971) : Nonmetric Approach for Investigation of Individual Differences in Multidimensional Scaling, 慶応義塾大学工学部学士論文. 